\title{
Efek Antidiare Ekstrak Air Bunga Nagasari (Mesua Ferrea L.) Terhadap Mencit BALB/c yang Diinduksi Minyak Jarak
}

\author{
(Antidiarrhoeal Activity of Water Extract of The Nagasari \\ Flowers (Mesua ferrea L.) in BALB/c Mice Induced by Castor \\ Oil)
}

\author{
PUTU MONIK ANANTA PUSPITARINI ${ }^{*}$, IMAN SURYA PRATAMA ${ }^{1}$, BAMBANG FAJAR \\ SURYADI ${ }^{2}$ \\ ${ }^{1}$ Program Studi Farmasi, Fakultas Kedokteran, Universitas Mataram \\ ${ }^{2}$ Program Studi Biologi, Fakultas MIPA, Universitas Mataram
}

Diterima 2 Januari 2018, Disetujui 22 Maret 2019

\begin{abstract}
Abstrak: Nagasari (Mesua ferrea L.) secara empiris telah digunakan untuk penanganan diare di Provinsi Nusa Tenggara Barat. Namun, keamanan dan kemanjuran dari nagasari belum dibuktikan secara ilmiah dalam model hewan. Penelitian ini bertujuan untuk mengevaluasi aktivitas antidiare ekstrak air bunga nagasari pada mencit $\mathrm{BALB} / \mathrm{c}$ yang diinduksi minyak jarak. Ekstrak air bunga nagasari $(0,4 \%(\mathrm{~b} / \mathrm{v}) ; 0,8 \%(\mathrm{~b} / \mathrm{v}) ;$ dan $1,6 \%(\mathrm{~b} / \mathrm{v}))$ diberikan pada 3 kelompok mencit, sedangkan kelompok kontrol negatif diberikan CMC-Na 1\% dan kelompok kontrol positif diberikan loperamide $0,7 \mathrm{mg} / \mathrm{kgBB}$ secara peroral satu kali sehari selama satu hari dan dilakukan pengamatan pada frekuensi dan konsistensi dari feses. Skrining fitokimia bunga nagasari mengandung flavonoid, saponin, dan fenolik. Ektrak air bunga nagasari pada konsentrasi 1,6\% menunjukkan aktivitas penghambatan yang signifikan terhadap minyak jarak sebanding dengan kontrol positif (indeks diare 0,$083 ; p>0,05$ ). Oleh karena itu, penelitian ini dapat mendukung penggunaan tradisional ekstrak air bunga nagasari sebagai antidiare.
\end{abstract}

Kata kunci: minyak jarak, indeks diare, nagasari.

\begin{abstract}
Nagasari (Mesua ferrea L.) is empirically used for management of diarrhea in West Nusa Tenggara Province. However, the safety and efficacy of nagasari have not been scientifically validated in an animal model. This study was aimed to evaluate the antidiarrheal activity of water extract of the nagasari flowers in BALB/c mice induced by castor oil. The water extract of nagasari flowers $(0,4 \%(\mathrm{w} / \mathrm{v}) ; 0,8 \%(\mathrm{w} / \mathrm{v})$; and $1,6 \%(\mathrm{w} / \mathrm{v}))$ was administered orally to 3 groups of mice, whereas negative controls received CMC-Na $1 \%$ and positive controls received loperamide $0,7 \mathrm{mg} / \mathrm{kgBW}$ orally once daily for 1 day. The frequency and consistency of feces were observed. The phytochemical screening of nagasari flowers contains flavonoid, saponin, and phenolic. Water extract of nagasari flowers at concentration 1,6\% showed significant inhibitory activity against castor oil comparable with positive controls (diarrhea index 0,$083 ; p>0,05$ ). Therefore, this study provides scientific support for the acclaimed traditional use of water extract of nagasari flowers for the treatment of diarrheal diseases.
\end{abstract}

Keywords: castor oil, diarrhea index, nagasari.

\footnotetext{
*Penulis korespondensi, HP 087759785540

Email:monikananta1@gmail.com
} 


\section{PENDAHULUAN}

DIARE merupakan keadaan buang air besar (BAB) lebih dari tiga kali dengan konsistensi encer dalam waktu 24 jam(1). Berdasarkan Profil Kesehatan di Provinsi NTB tahun 2015/2017, cakupan penderita diare belum mengalami penurunan secara signifikan yaitu sebanyak 158.993 dan 175.361 kasus $(2,3)$.

Berdasarkan WHO (1990) menunjukkan bahwa obat diare memiliki keterbatasan seperti efek samping. Selain itu, studi pola pengobatan diare menunjukkan toksisitas yang luas dan adanya penyalahgunaan di masyarakat(4). Hal ini mendorong pengembangan alternatif antidiare herbal karena bersifat multi-target dan memiliki kandungan kimia yang kompleks.

Nagasari (Mesua ferrea L.) merupakan salah satu tumbuhan tradisional yang digunakan sebagai antidiare. Hal ini tertulis dalam Lontar Dharma Usadha Kuranta Bolong, menyatakan bahwa bagian tumbuhan nagasari dapat digunakan sebagai obat mencret(5). Bunga nagasari diilustrasikan pada gambar 1 .

Secara in vitro, telah dilakukan penelitian yang menyatakan bahwa ekstrak metanol seluruh bagian bunga nagasari dosis $10 \mu \mathrm{g} / \mathrm{mL}, 50 \mu \mathrm{g} / \mathrm{mL}$ dan $>200$ $\mu \mathrm{g} / \mathrm{mL}$ menunjukkan daya hambat pada Escherichia coli melalui nilai KHM yaitu 2, 6 dan 14. Senyawa flavonoid yaitu mesuaferon- $A$ dan mesuaferon- $B$ diduga berperan dalam efek antibakteri(6).

Kajian ilmiah ekstrak air bunga nagasari sebagai antidiare secara in vivo masih terbatas. Oleh karena itu, penelitian ini bertujuan untuk mengevaluasi aktivitas antidiare ekstrak air bunga nagasari pada mencit $\mathrm{BALB} / \mathrm{c}$ yang diinduksi minyak jarak.

\section{METODE}

BAHAN. Bahan uji yang digunakan yaitu akuades, serbuk CMC-Na, kertas saring, mencit putih galur Balb/c dengan bobot 25-40 gram, minyak jarak, pakan mencit, sekam, simplisia bunga nagasari

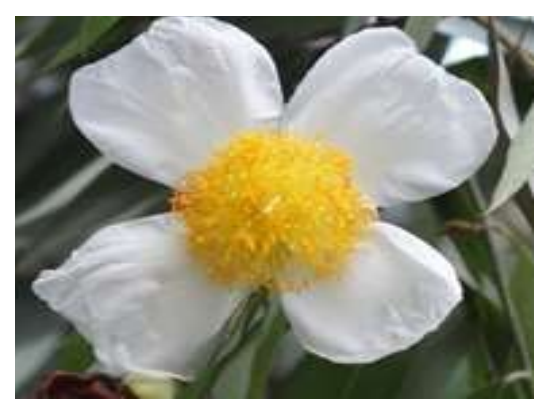

Gambar 1. Bunga Nagasari
(Mesua ferrea L.) dan Loperamid $2 \mathrm{mg}$.

METODE. Persiapan Tumbuhan Dan Determinasi. Bunga nagasari diperoleh di daerah Lingsar, Kabupaten Lombok Barat pada bulan Januari 2018. Determinasi tumbuhan dilakukan di Herbarium Bandungense SITH, Institut Teknologi Bandung, Bandung.

Penyiapan Simplisia Dan Pembuatan Ekstrak. Bunga nagasari dengan tangkai dicuci, dikeringkan, dihancurkan dengan blender kemudian diserbukkan hingga diperoleh serbuk dengan ukuran 35 mesh. Serbuk direbus dengan konsentrasi $0,8 \%(\mathrm{~b} / \mathrm{v})$ selama 15 menit dan disaring.

Uji Fitokimia. Uji fitokimia dilakukan pada senyawa metabolit sekunder seperti alkaloid, flavonoid, tannin, dan saponin berdasarkan prosedur pada jurnal Gul dkk, 2017(7).

Uji Antidiare Dari Ekstrak Air Bunga Nagasari. Penelitian ini dilakukan berdasarkan persetujuan komite etik No. 91/UN18.8/ETIK/2018. Mencit putih galur Balb/c diadaptasi dandibagi menjadi lima kelompok secara acak, meliputi kontrol negatif (larutan CMC-Na 1\%); kontrol positif (Loperamid $0,7 \mathrm{mg} / \mathrm{kgBB})$; ekstrak uji I $(0,4 \%(\mathrm{~b} / \mathrm{v}))$; ekstrak uji II $(0,8 \%(\mathrm{~b} / \mathrm{v}))$; dan ekstrak uji III $(1,6 \%(\mathrm{~b} / \mathrm{v}))$. Setelah 30 menit, mencit diberikan $1 \mathrm{~mL}$ minyak jarak. Pengamatan feses dilakukan tiap 30 menit selama 6 jam. Secara kualitatif ditentukan dari keberadaan darah dan lendir pada feses. Secara kuantitatif diukur menggunakan tiga indeks yaitu Loose Stool Incidence Rate (LSIR), Average Loose Stool Grade (ALSG) dan Diarrhea Index (DI) $(8,9,10)$. LSIR adalah rasio jumlah feses yang cair dengan total jumlah feses defekasi. LSG menggambarkan derajat feses yang cair dinilai berdasarkan diameter $(\mathrm{cm})$ feses pada kertas saring. LSG diklasifikasikan menjadi empat tingkat sesuai dengan diameter feses yang keluar : derajat $1(<1$ $\mathrm{cm})$; derajat $2(1-1,9 \mathrm{~cm})$; derajat $3(2-3 \mathrm{~cm})$; dan derajat $4(>3 \mathrm{~cm})$. ALSG adalah rata-rata dengan membagi LSG dengan jumlah feses yang cair. DI adalah perkalian antara LSIR dan ALSG.

Analisis Data. Normalitas data diuji dengan uji Shapiro-Wilk dan homogenitas data diuji dengan ANOVA. Uji statistik non-parametrik Kruskal Wallis untuk menentukan perbedaan bermakna antara kelompok variabel dependen dan independen $(p<0,05)$ dan uji lanjut Mann Whitney untuk menentukan perbedaan bermakna antara dua mean populasi yang berasal dari populasi yang sama $(\mathrm{p}<0,05)$. 


\section{HASIL DAN PEMBAHASAN}

Uji fitokimia menunjukkan ekstrak air bunga nagasari mengandung flavonoid, saponin dan senyawa fenolat yang ditunjukkan pada tabel 1 . Hal ini sesuai dengan pengujian sebelumnya pada ekstrak metanol bunga nagasari yang mengandung beberapa senyawa metabolit sekunder diantaranya flavonoid, saponin dan fenolat (11).

Efek antidiare ekstrak air bunga nagasari secara in vivo ditentukan melalui tiga parameter yaitu ALSG, LSIR dan DI.

LSIR pada kontrol positif dan kelompok ekstrak menunjukkan penurunan frekuensi diare yang berbeda bermakna dengan kontrol negatif. Peningkatan dosis dari ekstrak menyebabkan penurunan frekuensi diare. Ekstrak konsentrasi 1,6\% menunjukkan efek yang sebanding terhadap kontrol positif $(p>0,05)$.

ALSG menggambarkan tingkat konsistensi feses yang ditinjau dari ukuran diameter feses pada kertas saring. Kontrol positif dan kelompok ekstrak memiliki kemampuan mengurangi ukuran diameter feses yang berbeda bermakna dengan kontrol negatif. Ekstrak konsentrasi 1,6\% menunjukkan pengurangan ukuran diameter feses tertinggi dibandingkan dengan kelompok ekstrak lain dan efeknya sebanding terhadap kontrol positif ( $\mathrm{p}>0,05)$.

Kontrol positif dan kelompok ekstrak memiliki penurunan indeks diare yang berbeda bermakna dengan kontrol negatif. Ekstrak konsentrasi 1,6\%

Tabel 1. Skrining Fitokimia dari Ekstrak Air Bunga Nagasari

\begin{tabular}{c|c}
\hline Kandungan & Hasil \\
\hline Alkaloid & - \\
\hline Flavonoid & + \\
\hline Fenolat & + \\
\hline Saponin & + \\
\hline
\end{tabular}

menunjukkan penurunan indeks diare tertinggi dibandingkan dengan kelompok ekstrak lain dan efeknya sebanding terhadap kontrol positif $(\mathrm{p}>0,05)$. Berdasarkan ketiga parameter tersebut menunjukkan bahwa efektivitas tertinggi ekstrak yaitu pada konsentrasi 1,6\% sebanding dengan efek loperamid. Diduga kandungan senyawa metabolit yaitu flavonoid berperan dalam menurunkan ketiga parameter. Asam risinoleat yang dilepaskan oleh minyak jarak mengaktifkan sel otot polos usus dan uterus melalui reseptor prostanoid EP3 sebagai target untuk menginduksi diare(12). Flavonoid berperan menghambat pelepasan prostanoid EP3 sehingga motilitas usus dan sekresi hidroelektrolit yang berlebih dapat dihambat(13).

Ekstrak air bunga nagasari konsentrasi 1,6\% mengandung senyawa flavonoid sehingga dapat menghambat diare. Data toksisitas pada ekstrak etanol bunga nagasari menunjukkan dosis $500-2000 \mathrm{mg}$ / kgBB tidak menimbulkan tanda toksik pada mencit(14). Pada penelitian ini tidak ditemukan tanda toksisitas dan mortalitas pada mencit.

\section{SIMPULAN}

Ekstrak air bunga nagasari konsentrasi 1,6\% memiliki efek antidiare paling efektif ditunjukkan dengan penurunan indeks diare yang paling tinggi.

\section{SARAN}

Perlu dilakukan penelitian lanjut dengan metode transit intestinal untuk memperkuat efek antidiare dari ekstrak air bunga nagasari

Tabel 2. Nilai LSIR, ALSG, dan DI

\begin{tabular}{|c|c|c|c|}
\hline Kelompok & LSIR & ALSG & DI \\
\hline Ekstrak $0,4 \%$ & $0,603+0,025$ & $1,9+0,519$ & $1,053+0,253$ \\
\hline Ekstrak $0,8 \%$ & $0,2+0,173$ & $1+0$ & $0,2+0,173$ \\
\hline Ekstrak 1,6\% & $0,083+0,144^{*}$ & $0,33+0,577^{*}$ & $0,083+0,144^{*}$ \\
\hline Kontrol positif & +0 & +0 & +0 \\
\hline Kontrol negatif & $0,88+0,036$ & $1,553+0,254$ & $1,357+834,963$ \\
\hline
\end{tabular}

*) Hasil uji Mann Whitney menunjukkan tidak ada perbedaan bermakna dengan kelompok kontrol positif (Asymp. Sig. $>0,05 \%$ ). 


\section{DAFTAR PUSTAKA}

1. Tripathi KD. Essentials of medical pharmacology. Edisi ke-7, India : Jaypee Brothers Medical Publishers. 2013. p. 677.

2. Dinas Kesehatan Provinsi NTB. Profil Kesehatan Provinsi Nusa Tenggara Barat. NTB : Dinas Kesehatan Provinsi NTB. 2015.

3. Kementerian Kesehatan Republik Indonesia. Data dan Informasi Kesehatan Indonesia 2017. Jakarta : Kementerian Kesehatan Republik Indonesia. 2018.

4. World Health Organization. The rational use of drugs in the management of acute diarrhoea in children. Geneva : World Health Organization. 1990.

5. Listiawati NP, Juniawan IBH, Anom AAIA, Sudarsana IWG, and Wibawa IG JS. Dharma usadha kuranta bolong klimosadha Sang Hyang Klimosadha. Diterjemahkan oleh Listiawati NP, Juniawan IBH, Anom AAIA, Sudarsana IWG, and Wibawa IG JS. Mataram : STAHN Gde Pudja Mataram. 2016.

6. Mazumder R, Dasridar SG, Basu SP, Mazumder A, and Singh SK. Antibacterial potentiality of Mesua ferrea Linn. flowers. Phytotherapy Research. 2004. 18 : 82426.

7. Gul R, Jan S. U, Faridullah S, Sherani S, and Jahan N. Preliminary phytochemical screening, quantitative analysis of alkaloids, and antioxidant activity of crude plant extracts from Ephedra intermedia Indigenous to Balochistan. The Scientific World Journal.2017. 2017 : 1-7.

8. Hui H, Chen M, Li G, Feng H, et al. Andrographolide attenuates senna- and castor oil-induced diarrhea in mice. Latin American Journal of Pharmacy. 2013. 32(8): 1113-7.

9. Han X, Pang Y, Liu S, Tan Z, Tang S, Zhou C, et al. Antidiarrhea and antioxidant activities of honokiol extract from Magnoliae officinalis cortex in mice. Tropical Journal of Pharmaceutical Research. 2014. 13 (10): 1643-51.

10. Yu J, Zhang Y, Song X, Yang Y, Jia R, Chen X, et al. Effect of modified Pulsatilla powder on enterotoxigenic Escherichia coli O101-induced diarrhea in mice. Hindawi. 2017. 2017: 11.

11. Sahu AN, Hemalatha S, and Sairam K. Quality control studies of Mesua ferrea Liin. flowers. International Journal of Herbal Medicine.2013. 1 (2):124-30.

12.Tunaru S, Althoff TF, Nusing RM, Diener M, and Offermanns S. Castor oil induces laxation and uterus contraction via ricinoleic acid activating prostaglanding EP3 receptors. Proceedings of the National Academy of Science of the United States of America. 2012. 109 (23): 9179-84.

13. Maniyar Y, Bhixavatimath P, and Agashikar NV. Antidiarrheal activity of flower of Ixora coccinea Linn. in rats. Journal of Ayurveda and Integrative Medicine. 2010. 1 (4): 287-91.

14.Tiwari PK, Irchhaiya R, and Jain SK. Evaluation of anticonvulsant activity of Mesua ferrea Liin. ethanolic flower extract. International Journal of Phamacy and Life Sciences, 2012.3 (3): 1507-08. 